\title{
Hereditary Sideroblastic Anemia
}

National Cancer Institute

\section{Source}

National Cancer Institute. Hereditary Sideroblastic Anemia. NCI Thesaurus. Code C35262.

An inherited form of sideroblastic anemia. 